Article

\title{
In Vitro Study of Biocontrol Potential of Rhizospheric Pseudomonas aeruginosa against Pathogenic Fungi of Saffron (Crocus sativus L.)
}

\author{
Shuang Hu, Xingxing Wang, Wenjing Sun, Lili Wang and Wankui Li *
}

Citation: Hu, S.; Wang, X.; Sun, W.; Wang, L.; Li, W. In Vitro Study of

Biocontrol Potential of Rhizospheric Pseudomonas aeruginosa against Pathogenic Fungi of Saffron (Crocus sativus L.). Pathogens 2021, 10, 1423. https://doi.org/10.3390/ pathogens10111423

Academic Editor: Linda D. Hazlett

Received: 10 August 2021

Accepted: 31 October 2021

Published: 2 November 2021

Publisher's Note: MDPI stays neutral with regard to jurisdictional claims in published maps and institutional affiliations.

Copyright: (c) 2021 by the authors. Licensee MDPI, Basel, Switzerland. This article is an open access article distributed under the terms and conditions of the Creative Commons Attribution (CC BY) license (https:// creativecommons.org/licenses/by/ $4.0 /)$.
Institute of Chinese Materia Medica, Shanghai University of Traditional Chinese Medicine, Shanghai 201203, China; 15077877510@163.com (S.H.); wangxingrg@126.com (X.W.); sunwenjingyy@126.com (W.S.); biol2006@126.com (L.W.)

* Correspondence: bio5210@126.com

\begin{abstract}
Plant rhizosphere soil contains a large number of plant-growth promoting rhizobacteria, which can not only resist the invasion of pathogenic microorganisms and protect plants from damage, but also promote the growth and development of plants. In this study, Pseudomonas aeruginosa strain YY322, isolated and screened from the rhizosphere soil of saffron (Crocus sativus L.), was found through a plate confrontation experiment to show highly effectual and obvious antagonistic activity against the pathogens of saffron, including Fusarium oxysporum, Fusarium solani, Penicillium citreosulfuratum, Penicillium citrinum and Stromatinia gladioli. In addition, the volatile organic compounds of strain YY322 had great antagonistic activity against these pathogens. Observation under a scanning electron microscope and transmission electron microscope reflected that strain YY322 had a significant effect on the hyphae and conidia of F. oxysporum and F. solani. Through the detection of degrading enzymes, it was found that $P$. aeruginosa can secrete protease and glucanase. The plant growth promoting performance was evaluated, finding that strain YY322 had the functions of dissolving phosphorus, fixing nitrogen, producing siderophore and producing $\mathrm{NH}_{3}$. In addition, whole genome sequencing analysis indicated that the YY322 genome is comprised of a 6,382,345-bp circular chromosome, containing 5809 protein-coding genes and 151 RNA genes. The P. aeruginosa YY322 genome encodes genes related to phenazine ( $p h z A B D E F G I M R S$ ), hydrogen cyanide(HCN) (hcnABC), surfactin ( $s r f A A)$, salicylate (pchA), biofilm formation (flgBCDEFGHIJKL, $\operatorname{mot} A B, e f p, h f q)$, and colonization $(\min C D E, y j b B, l y s C)$. These results collectively indicated the role of $P$. aeruginosa YY322 in plant growth enhancement and biocontrol mechanisms. All in all, this study provides a theoretical basis for P. aeruginosa as the PGPR of saffron, paving the way for the subsequent development and utilization of microbial fertilizer.
\end{abstract}

Keywords: Pseudomonas aeruginosa; saffron; rhizosphere; antagonistic activity; biological control; PGPR

\section{Introduction}

Saffron (Crocus sativus L.) is a well-known dye and spice, widely cultivated in India, Iran, China, Egypt, France, Greece, Israel, Italy, Spain, Turkey and other countries [1]. Saffron is an essential medicinal plant in China, purported to have the ability of promoting blood circulation, removing blood stasis, cooling blood, resolving toxins, relieving depression, and calming nerves. However, because of its low output and high values, saffron is costly and is referred to as "red gold" [2,3]. At present, saffron is widely cultivated on Chongming Island in Shanghai. However, many corms have rotted due to long-term continuous cropping and other factors, resulting in a decline in saffron yield and quality. Although using chemical fertilizers and pesticides reduces the occurrence and development of diseases, they inevitably contribute to environmental pollution and safety issues with medicinal materials. 
The term rhizosphere, coined by German scientist Lorenz Hiltner in 1904, refers to a micro-domain environment influenced by plant root activities and differs from soil in physical, chemical, and biological properties. It is considered as the second genome of plants and is a hotspot for plant-soil-microbe interactions [4-6]. Due to unique environment of rhizosphere soil, numerous microorganisms gather in this area, where they play a vital role in the life history of plants $[7,8]$. Numerous plant growth-promoting rhizobacteria (PGPR) capable of strengthening plant nutrient absorption and immunological function have been isolated from rhizosphere soil, and a number of these have been converted into microbial fertilizers with favorable results [9-11].

Currently, the most extensively investigated PGPR includes Pseudomonas, Bacillus, Agrobacterium, Eriwinia, Flavobacterium, Pasteuria, Serratia, Enterobacter, etc. Pseudomonas is a type of obligate aerobic gram-negative rod-shaped bacteria widely distributed in nature and has garnered widespread interest due to its intimate association with human activities. Pseudomonas grows rapidly and can adapt to the natural environment. Aside from this, it can effectively antagonize the occurrence and development of plant pathogens by secreting a series of metabolites and can help plants to absorb and utilize nutrients [12]. In addition, it is easily selected and bred through genetic mutation or modification, then inoculated into plants' rhizospheres using bacterialization of seeds to perform its function [13]. Currently, the main types of Pseudomonas classified as PGPR are P. putida [14], P. aeruginosa [15], P. fluorescens [16,17], P. chlororaphis [18], and P. Parafulva [19].

Herein, 85 strains of bacteria were isolated from the rhizosphere soil of saffron. Among them, strain YY322 exhibited a good antagonistic effect against the five pathogens of saffron. Combining physiological and biochemical tests and molecular biology identification, it was identified as P. aeruginosa. The strain YY322 could destroy the hyphae and conidia of pathogens, as observed under a scanning electron microscope (SEM) and transmission electron microscope (TEM). Moreover, hydrolytic enzymatic (chitinase, protease, cellulase, and glucanase) activity and plant growth-promoting (PGP) potential (phosphate solubilization, potassium dissolution, atmospheric nitrogen fixation, siderophore production, indole-3-acetic acid (IAA) and ammonia $\left(\mathrm{NH}_{3}\right)$ production, 1-aminocyclopropane1-carboxylate (ACC) deaminase activity) of the strain were tested, discovering that the strain possessed good performance. Finally, we performed whole-genome sequencing of the bacterium to further explore its antagonistic and growth-promoting mechanisms. This article provides evidence to prove that P. aeruginosa can be used as PGPR in the production of saffron, laying a theoretical foundation for the development and utilization of microbial fertilizer.

\section{Results}

\subsection{Isolation and Screening of Antagonistic Bacteria}

A total of 85 strains of bacteria were isolated from saffron rhizosphere soil. After several screenings, it was found that the antagonistic effect of strain YY322 was the best, with inhibitory rates for Fusarium oxysporum, Fusarium solani, Penicillium citreosulfuratum, Penicillium citrinum, and Stromatinia gladioli of $73.17 \%, 62.20 \%, 23.16 \%, 49.17 \%$, and 79.76\%, respectively (Figure 1). During the process of plate confrontation, not only was the growth of pathogenic fungi significantly inhibited, but the morphological characteristics of strain YY322 were also changed compared with the normal state, indicating that it may have produced some unknown antifungal substances. The strain is currently stored in the China Center for Type Culture Collection under the number CCTCC M 2021208 YY322. 


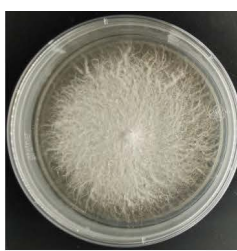

A1

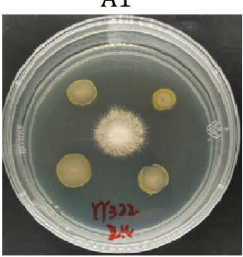

A2

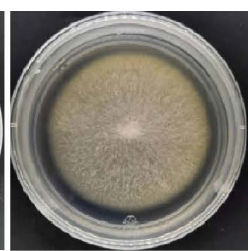

B1

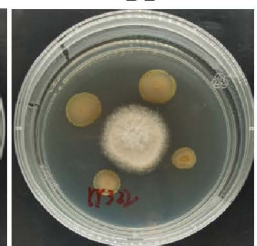

B2

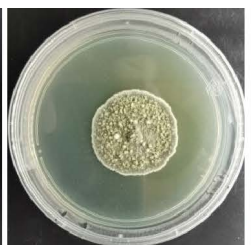

C1

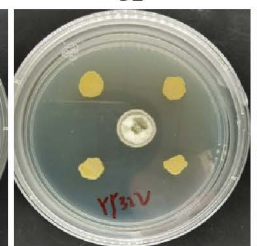

C2

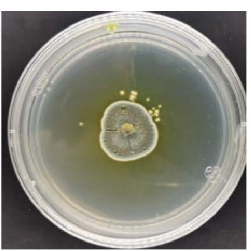

D1

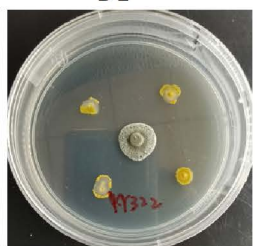

D2
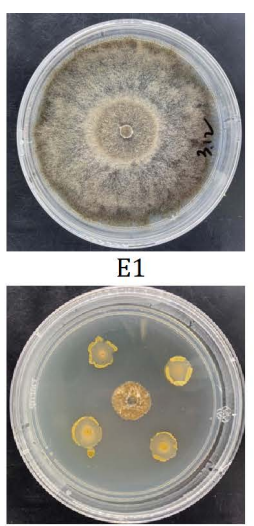

E2

Figure 1. Antagonistic effect of strain YY322 on five pathogens cultivated on PDA medium for one to two weeks. (A) F. oxysporum, (B) F. solani, (C) P. citreosulfuratum, (D) P. citrinum, (E) S. gladioli (1) control, (2) treatment.

\subsection{Strain YY322: Fusarium spp. Interaction Study by SEM and TEM}

SEM indicated that the hyphae and conidia of Fusarium spp. under the action of strain YY322 were changed significantly compared with the control group. Hyphae were round and full in the control group, with complete morphology and structure, smooth surface, and uniform thickness, whereas conidia were normal spindle-shaped, moderate in size, and demonstrating a good growth state. F. oxysporum affected by strain YY322 had numerous broken hyphae, with an uneven surface, severe segmentation, abnormal apex development, and malformed conidia. F. solani affected by strain YY322 caused seriously damaged hyphae, with surface shrinkage and leakage of contents. In addition, it possessed only a few large conidia and no small conidia (Figure 2). Under TEM, it could be observed that compared with the control group, the internal structure of Fusarium spp. under the action of strain YY322 was severely damaged. In the control group, the evenly distributed hyphae were regularly round and exhibited clear boundaries. The cell wall and membrane remained intact and compact, and the cytoplasm was well-distributed, maintaining a normal growth state. The cell walls of the hyphae of F. oxysporum affected by strain YY322 ruptured, resulting in leakage of the contents. The number of vacuoles decreased, but their volume increased. In addition, the cytoplasm was turbid and chaotic. F. solani, affected by strain YY322, exhibited numerous immature conidia gathered together, and the shape of the hyphae section was abnormal. The cell wall was thickened, the cytoplasm was mixed and black, and the vacuole almost disappeared (Figure 3).

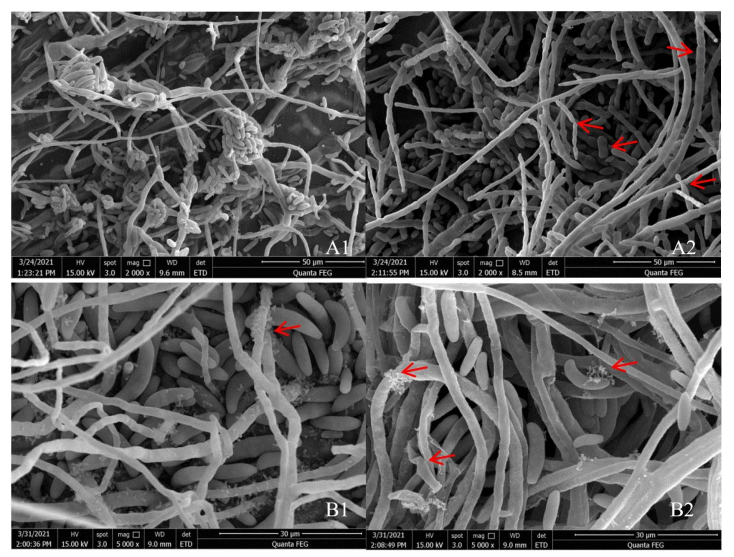

Figure 2. Observation of the morphological changes of hyphae and conidia under SEM. (A) F. oxysporum; (B) F. solani (1) control: the hyphae and conidia showed normal growth, (2) treatment: the surface of the hyphae is shrunk and broken, and its contents leak out; the conidia develop abnormally and decrease in number (arrowheads). 

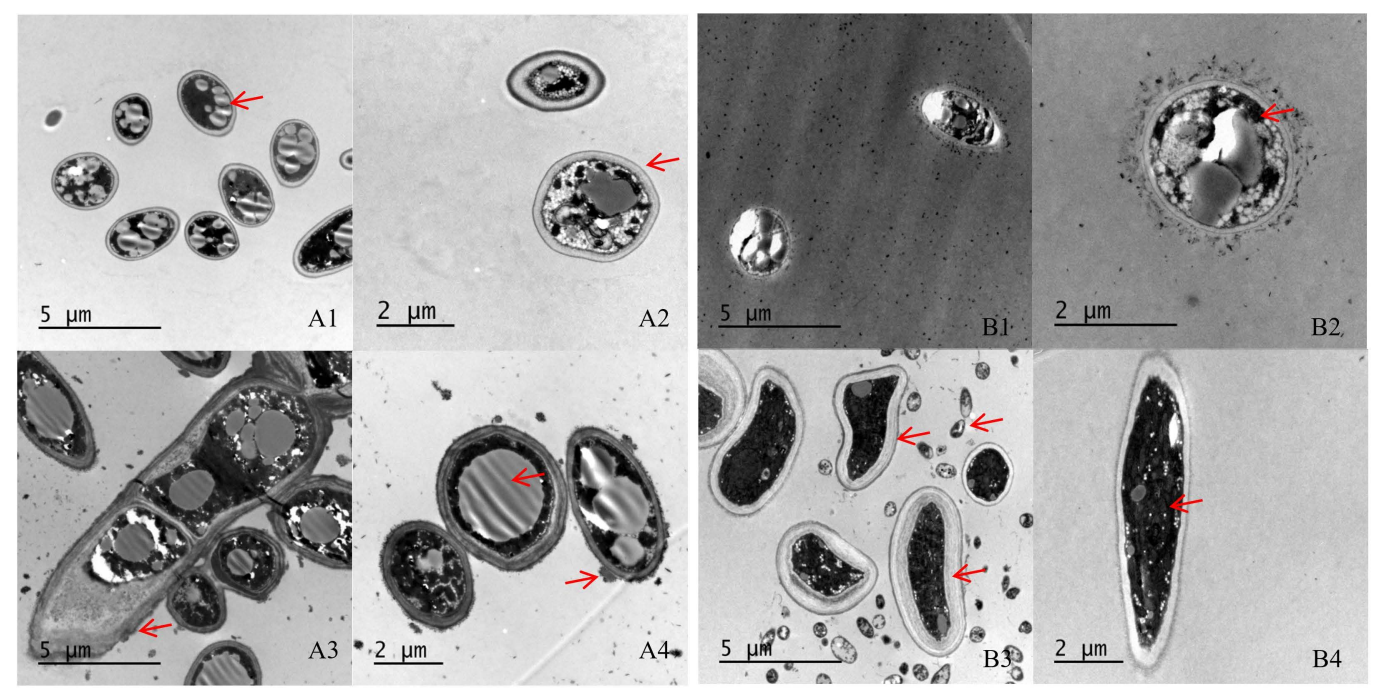

Figure 3. Observation of the changes in the internal structure of hyphae under TEM. (A) F. oxysporum; (B) F. solani $(\mathbf{1}, \mathbf{2})$ control: the evenly distributed hyphae have clear boundaries, the cell wall and cell membrane structure are complete, and the cytoplasm is in a normal state, $(3,4)$ treatment: the section of hyphae is irregular, the cell wall is thickened, the cytoplasm is turbid and chaotic, and the vacuole develops abnormally (arrowheads).

\subsection{Inhibitory Effect of VOCs of Strain YY322 on Mycelial Growth}

Since we discovered that the strain YY322 could produce a special smell when cultured, we tested the antifungal effect of its VOCs, and the results showed it demonstrated a pronounced inhibitory effect on F. oxysporum and F. solani, with inhibition rates of $90.24 \%$ and $89.02 \%$, respectively. Intriguingly, a few hyphae of both pathogens could still be observed spreading to the entire plate (Figure 4).

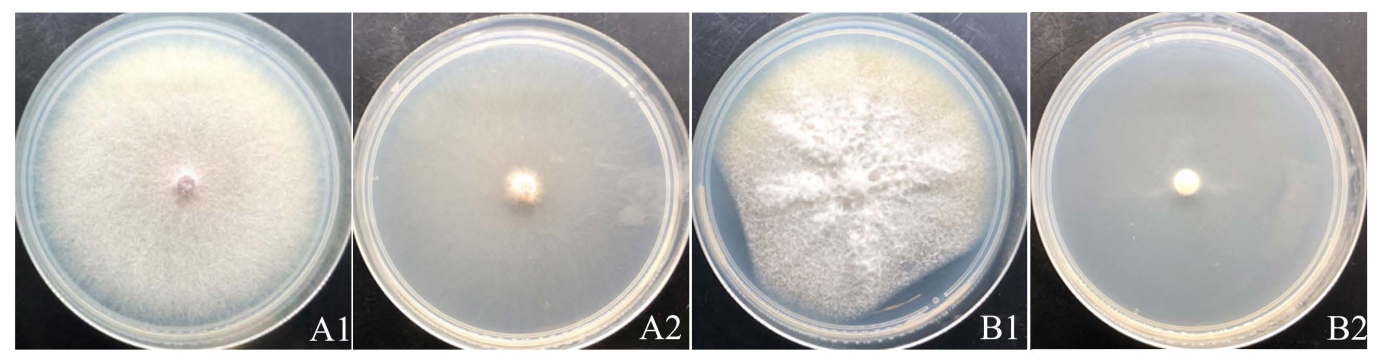

Figure 4. Antifungal activity of VOCs: (A) F. oxysporum; (B) F. solani (1) control, (2) treatment.

\subsection{Identification of Strain YY322}

The single colony of strain YY322 on LB medium after being incubated for $24 \mathrm{~h}$ at $30^{\circ} \mathrm{C}$ was nearly round, relatively flat, light yellow-green, not smooth, and opaque with irregular edges (Figure 5A). Under SEM, the strain YY322 was observed to be rod-shaped, with a size of about $0.5 \mu \mathrm{m} \times 2 \mu \mathrm{m}$ (Figure 5B). Subsequently, the strain YY322 was identified as P. aeruginosa according to its $16 \mathrm{~S}$ rDNA sequence phylogenetic tree (Figure 6), deposited in GenBank under accession number MZ026485. Finally, according to physiological and biochemical tests, strain YY322 was confirmed as P. aeruginosa (Table 1). 


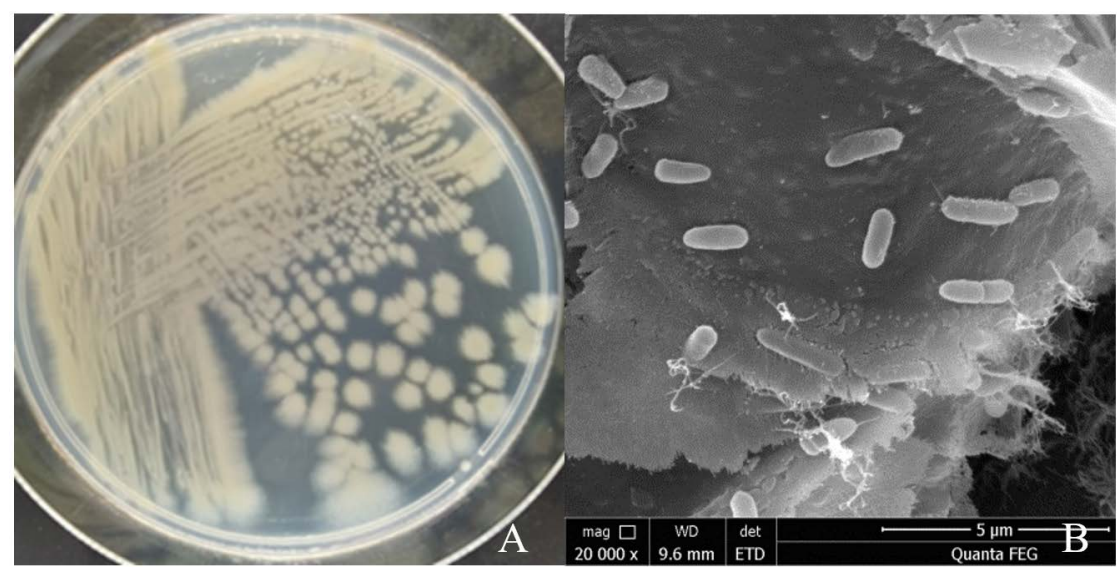

Figure 5. Morphology of strain YY322: (A) colony morphology and (B) microscopic morphology.

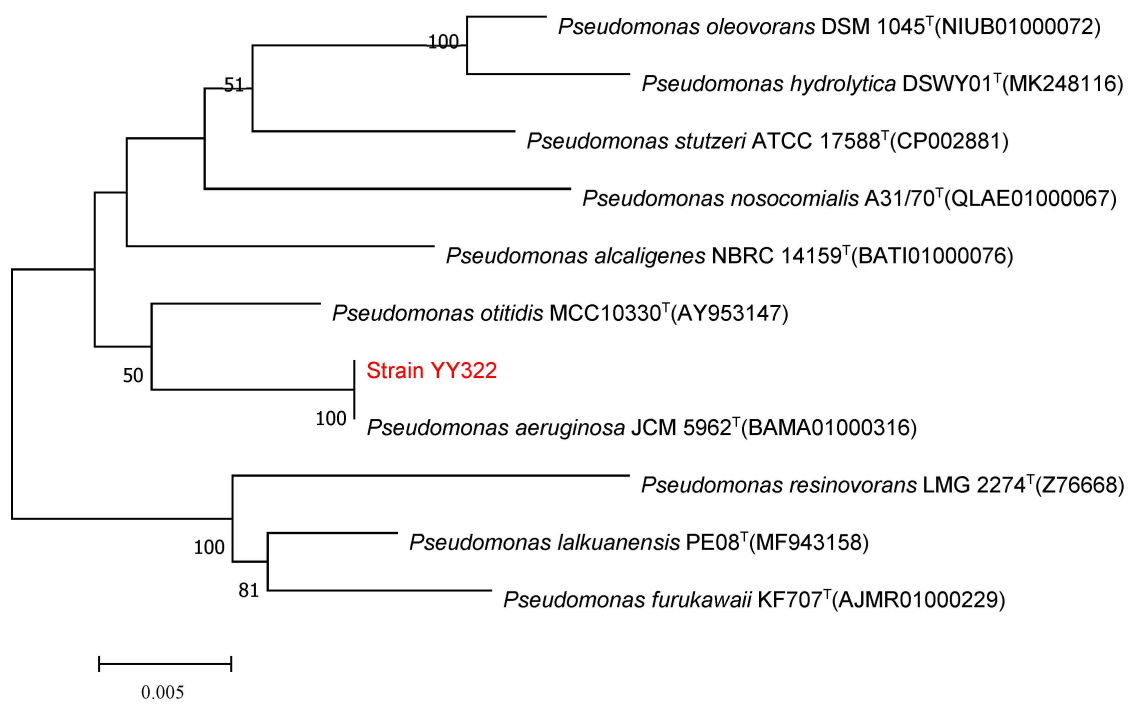

Figure 6. 16S rDNA sequence phylogenetic tree of strain YY322: the numbers at the nodes indicate the levels of bootstrap support (\%) based on 1000 reassembled datasets, in which only the branches with $>50 \%$ bootstrap support are labeled, and the superscript " $\mathrm{T}$ " indicates the model strain.

Table 1. Morphological, biochemical, plant growth-promoting, and antagonistic activity of strain YY322.

\begin{tabular}{cccc}
\hline $\begin{array}{c}\text { Physiological and Biochemical } \\
\text { Characterization }\end{array}$ & Result & $\begin{array}{c}\text { Hydrolytic Enzyme Activities } \\
\text { and PGP Attributes }\end{array}$ & Result \\
\hline gram reaction & - & chitinase & - \\
growth at $4^{\circ} \mathrm{C}$ & - & protease & + \\
growth at $41^{\circ} \mathrm{C}$ & + & cellulase & - \\
oxidase & + & glucanase & + \\
catalase & + & phosphate solubilization & + \\
urease & + & potassium dissolution & - \\
lipase & + & nitrogen fixation & + \\
MR & - & ACC deaminase enzyme & - \\
V-P & - & IAA production & - \\
gelatin liquefaction & + & NH H $_{3}$ production & + \\
starch hydrolysis & - & siderophore production & + \\
milk coagulation & + & & \\
H ${ }_{2}$ S production & - & \\
nitrate reduction & + & \\
citrate utilization & + &
\end{tabular}

Abbreviations: +, positive for test; - , negative for test. 


\subsection{Hydrolytic Enzymes Activities of Strain YY322}

According to the experimental phenomenon, strain YY322 exhibited strong protease activity and weak glucanase activity but lacked cellulase and chitinase activities (Supplementary materials, Figure S1).

\subsection{Screening of Plant Growth-Promoting Attributes of Strain YY322}

The strain YY322 could fix nitrogen, solubilize organic and inorganic phosphate, and produce siderophore and $\mathrm{NH}_{3}$, but did not dissolve potassium or produce IAA and ACC deaminase enzyme (Supplementary Materials, Figure S2).

\subsection{WGS Analysis of Strain YY322}

The complete genome of YY322 was composed of a 6,382,345 bp circular chromosome with a $66.47 \%$ GC content (GenBank number: CP080518, Figure 7), which contained 5809 protein-coding genes (CDSs), 64 tRNA genes, 12 rRNA genes, and 75 other ncRNA. CRISPR analysis forecast seven sequences with confirmed type. Detailed information is provided in the Supplemental Data Supplementary materials (Tables S1-S3).

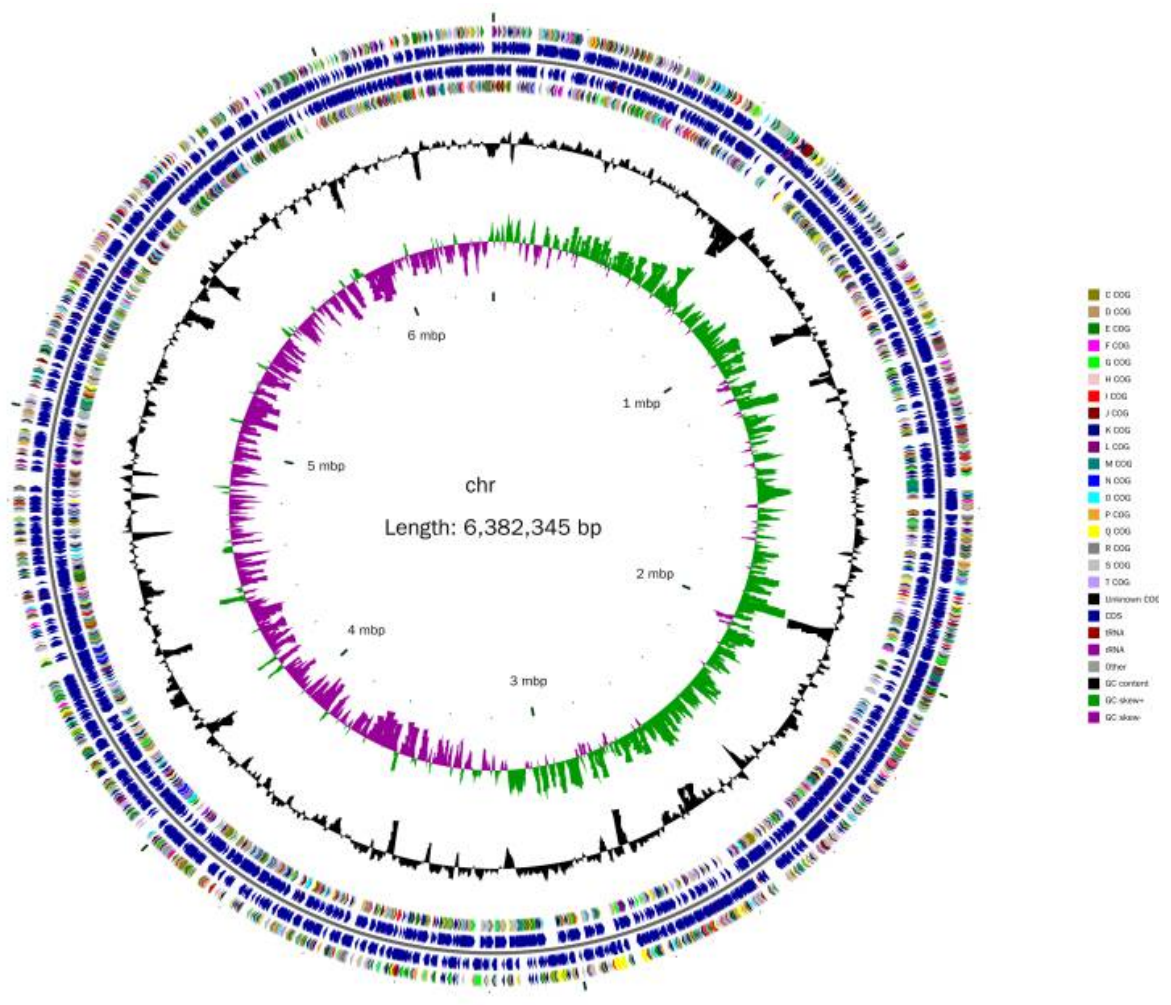

Figure 7. YY322 genome circle: from inside to out, the first circle represents the scale, the second circle represents GC Skew, the third circle represents GC content, the fourth and seventh circles represent the COG (Cluster of Orthologous Groups of proteins) to which each CDS (Coding sequence) belongs, and the fifth and sixth circles represent the position of CDS, tRNA, and rRNA in the genome.

In the comparison of different databases, there were 4377 protein-encoding genes in the GO database, 5254 protein-encoding genes in the eggNOG database, and 3192 proteinencoding genes in the KEGG database. GO analysis was used to categorize genes into three categories according to matches with known sequences. The seven main pathways were biological process (GO: 0008150, 4114 genes), molecular function (GO: 0003674, 3904 genes), cell (GO: 0005623, 1430 genes), biosynthetic process (GO: 0009058, 1428 genes), cellular nitrogen compound metabolic process (GO: 0034641, 1368 genes), cellular component (GO: 0005575, 1310 genes) and ion binding (GO: 0043167, 1269 genes) (Figure 8). The eggNOG classification annotation showed that $90.45 \%$ of protein-encoding genes could be annotated to eggnog; however, the number of unknown function genes was the highest and 
up to 1407 , accounting for $24.22 \%$ of total protein-encoding genes. Among these known functional genes, the genes for transcription were the most abundant, with 455 genes accounting for $7.83 \%$, followed by 436 genes for regulating amino acid transport and metabolism, accounting for 7.51\% (Figure 9). Of the eight classifications of KEGG pathways, brite hierarchies (protein families: signaling and cellular processes, genetic information processing, metabolism) contained the highest number of genes, followed by metabolism (amino acid and carbohydrate metabolism) (Figure 10).

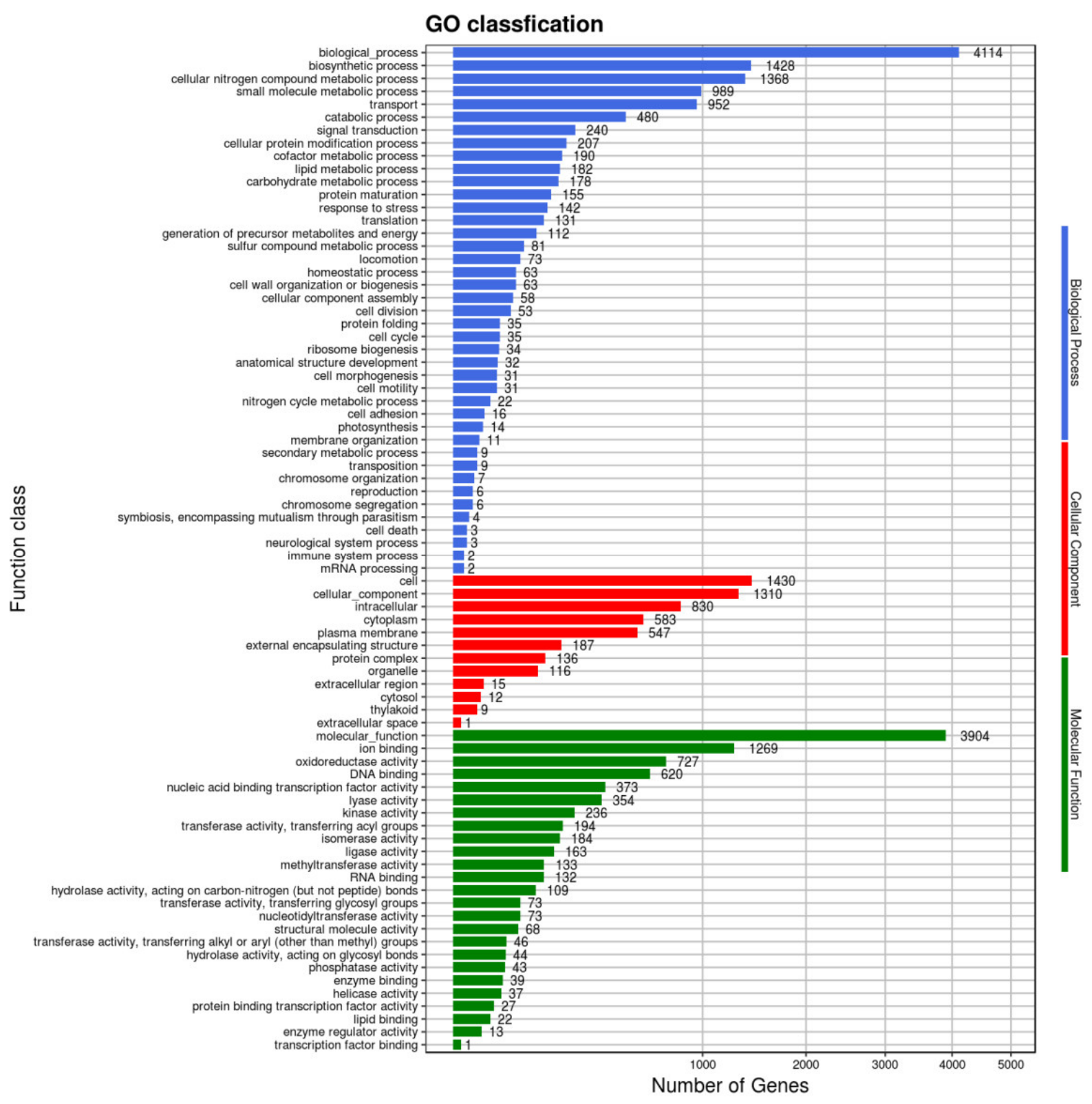

Figure 8. Clusters of GO annotation. 


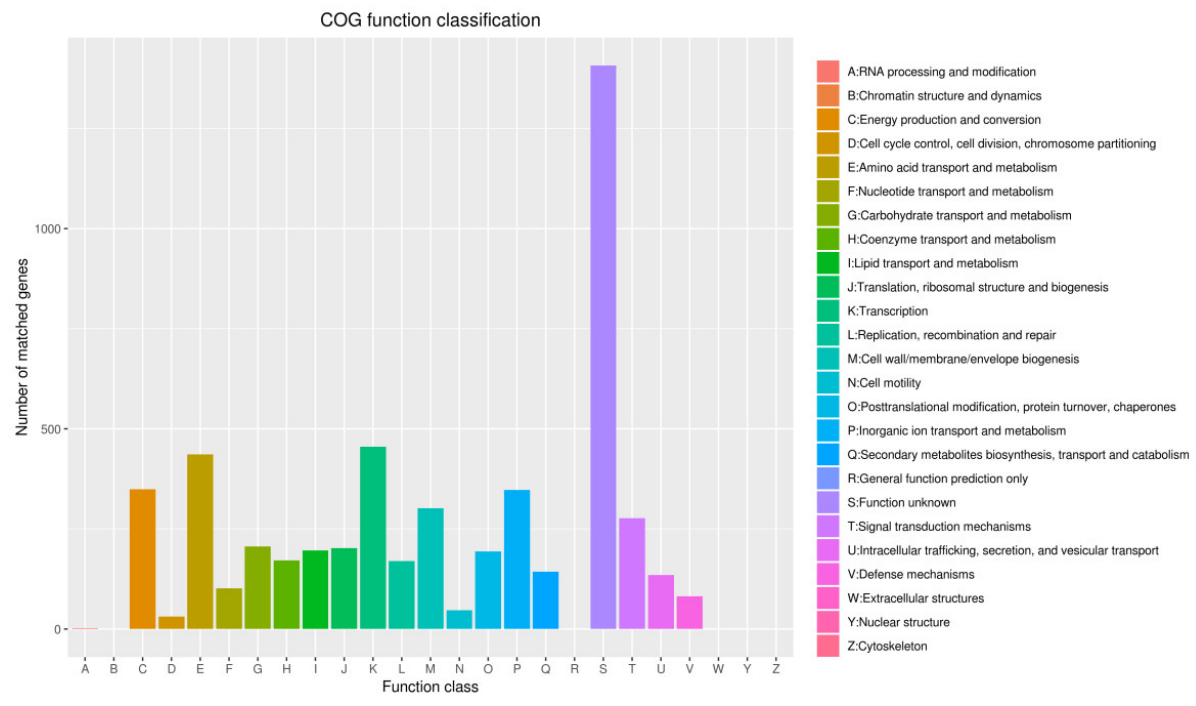

Figure 9. Clusters of COG annotation: Number of matched genes-(A) 2, (B) 0, (C) 349, (D) 31, (E) 436, (F) 102, (G) 206, (H) 171, (I) 196, (J) 202, (K) 455, (L) 170, (M) 302, (N) 45, (O) 194, (P) 347, (Q) 143, (R) 0, (S) 1407, (T) 277, (U) 135, (V) 82, (W) 0, (Y) 0, (Z) 0.

\section{KEGG classfication}

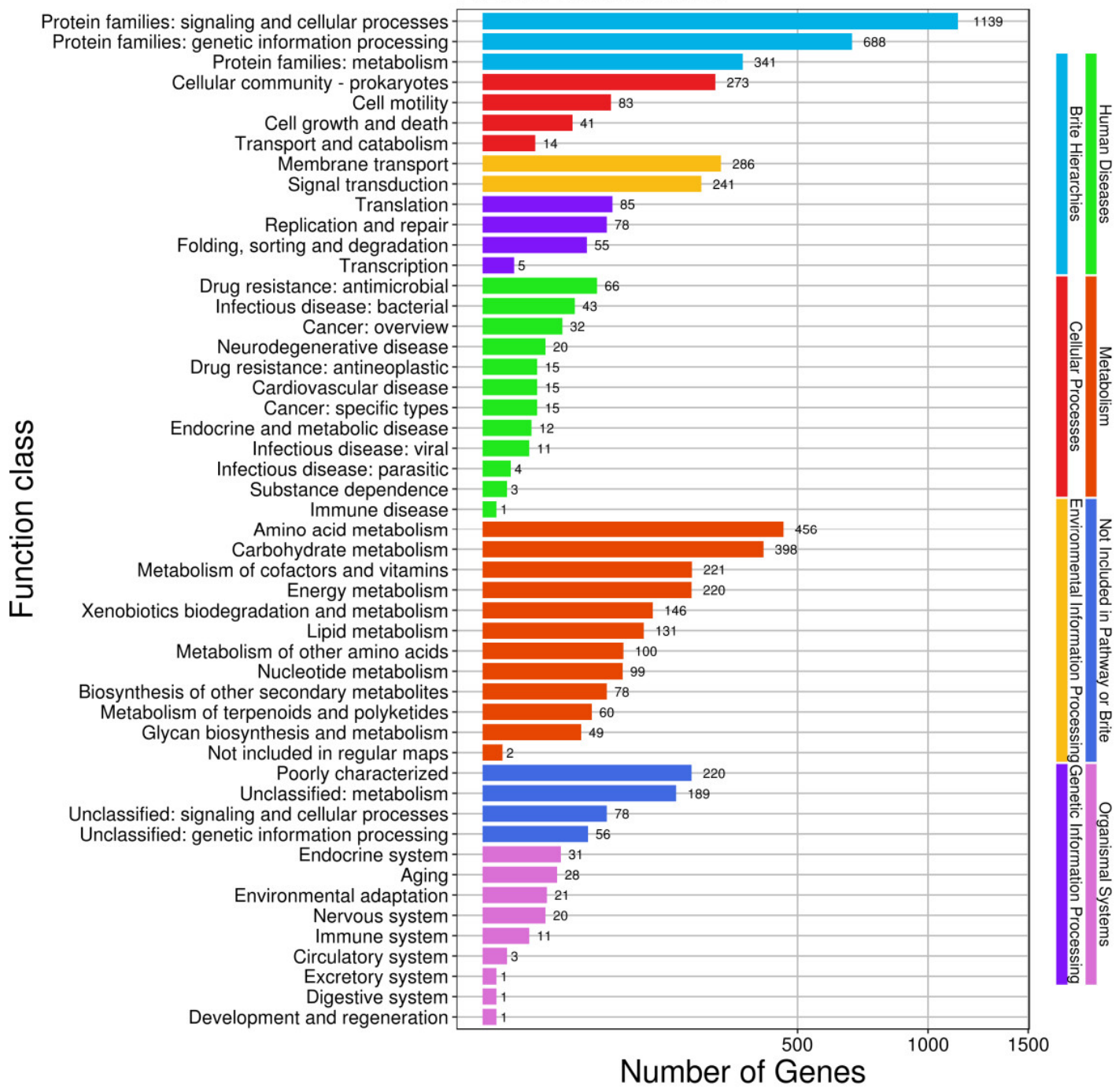

Figure 10. Clusters of KEGG annotation. 
The CAZymes analysis revealed that the glycosyl transferase (GTs; 40 genes) family was the major category, followed by carbohydrate esterases (CEs; 34 genes), and glycoside hydrolases (GHs; 33 genes) (Figure 11). Data obtained from antiSMASH 6.0.1 showed strain YY322 encodes 15 secondary metabolite biosynthesis gene clusters (BGCs), including four NRPS (non-ribosomal peptide synthetase), two NRPS-like, two RiPP (other unspecified ribosomally synthesized and post-translationally modified peptide product cluster), two phenazine, two hserlactone, one NAGGN (N-acetylglutaminylglutamine amide), one T1PKS (type I polyketide synthase), one T3PKS (type III polyketide synthase), one redox-cofactor, one thiopeptide, and one betalactone. Three of these shared $100 \%$ similarity with the accession sequence, which encoded coelibactin, pyocyanine and L-2-amino-4-methoxy-trans-3-butenoic acid (Table 2).

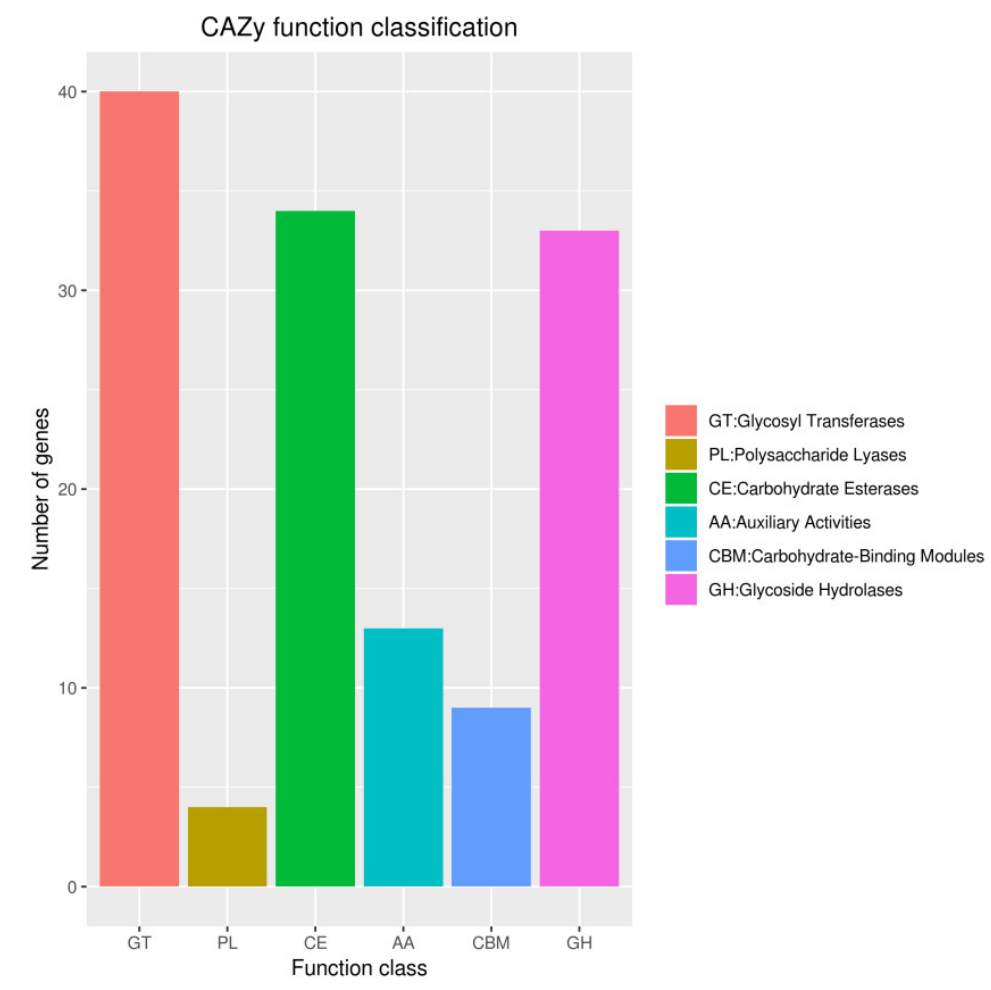

Figure 11. Gene count distributions of carbohydrate-active enzyme families.

Table 2. Results of the search for antimicrobial gene clusters in the genome of strain YY322.

\begin{tabular}{|c|c|c|c|c|c|}
\hline Region & Type & From & To & Most Similar Known Cluster & Similarity \\
\hline 1 & NRPS, phenazine & 738,712 & 795,458 & marinophenazine $\mathrm{A} /$ phenaziterpene $\mathrm{A}$ & $30 \%$ \\
\hline 2 & RiPP-like & 909,671 & 920,361 & - & - \\
\hline 3 & NRPS-like & 926,710 & 969,065 & - & - \\
\hline 4 & hserlactone & $1,612,259$ & $1,632,202$ & - & - \\
\hline 5 & NAGGN & $1,635,525$ & $1,650,285$ & - & - \\
\hline 6 & NRPS & $1,753,238$ & $1,800,066$ & - & - \\
\hline 7 & RiPP-like & $1,828,970$ & $1,839,824$ & - & - \\
\hline 8 & T3PKS,T1PKS & $2,602,677$ & $2,661,176$ & pyoluteorin & $100 \%$ \\
\hline 9 & NRPS & $2,835,654$ & $2,949,679$ & pyoverdin & $24 \%$ \\
\hline 10 & NRPS & $3,021,594$ & $3,073,805$ & L-2-amino-4-methoxy-trans-3-butenoic acid & $100 \%$ \\
\hline 11 & redox-cofactor & $3,422,524$ & $3,444,653$ & lankacidin $\mathrm{C}$ & $13 \%$ \\
\hline 12 & thiopeptide & $3,493,168$ & $3,526,171$ & oxalomycin B & $6 \%$ \\
\hline 13 & phenazine & $3,528,349$ & $3,549,361$ & pyocyanine & $100 \%$ \\
\hline 14 & hserlactone & $4,040,057$ & $4,060,662$ & - & - \\
\hline 15 & $\begin{array}{l}\text { NRPS-like, } \\
\text { betalactone }\end{array}$ & $4,255,904$ & $4,297,412$ & pyoverdin & $2 \%$ \\
\hline
\end{tabular}




\section{Discussion}

As a traditional Chinese medicine in China, saffron has been revealed by many researchers to have remarkable benefits as a result of current research advancements [20,21]. To meet the domestic market demand, the cultivation area of saffron has gradually expanded. However, due to factors such as corm origin, planting technology, and climate environment, saffron diseases have become increasingly prevalent, resulting in massive losses to farmers and impeding the saffron industry's continued development [22]. At present, the most pathogenic microorganism for saffron is F. oxysporum. Once it is allowed to multiply and expand in the field, it has a devastating impact on saffron growth. F. oxysporum, one of the top ten plant pathogenic fungi, is a ubiquitous soil-borne pathogen that leads to vascular wilt on a wide range of plants [23]. Although chemical pesticides have significantly reduced the infection of pathogens such as F. oxysporum, they leave pesticide residues and may affect the quality of saffron medicinal materials. Thereby, it is imperative to seek new technical means to inhibit these pathogenic fungi in order to achieve the purpose of protecting saffron.

The discovery of PGPR with antagonistic and PGR effects from the rhizosphere has become a current research focus. Plants can release chemical signals in response to their own requirements, which significantly influence the composition and function of rhizosphere soil microorganisms, contributing to promoting plant growth and resisting biotic and abiotic stress. Yuan's study suggested that, when exposed to aboveground pathogens, plants will recruit beneficial rhizosphere communities by modification of plant exudation patterns so as to benefit subsequent plant generations [24]. As a result, the rhizosphere of healthy plants usually contains a lot of PGPR. Yang's research indicated that seven PGPR from the field-grown barley rhizosphere could increase plant growth promotion and biocontrol of Fusarium wilt in watermelon [11].

In this study, strain YY322 was isolated from the rhizosphere soil of healthy saffron and had a noticeable antagonistic effect on the five pathogenic fungi of saffron. According to its morphological and biochemical characteristics and 16S rRNA gene sequencing, strain YY322 was identified as P. aeruginosa. P. aeruginosa is widely distributed in the natural environment; it is a conditional pathogen for humans, particularly for burn patients, cancer patients, immunodeficiency patients, and cystic fibrosis patients. Recent research has demonstrated that it can also be utilized as PGPR. Chandra discovered that P. aeruginosa isolated from the rhizosphere of Valeriana wallichi was subjected to in vitro biocontrol activity against F. oxysporum, Alternaria alternata, and Aspergillus flavus and displayed plant growth promotion rhizobacterial activity [15]. Singh discovered that as an effective colonizer in sugarcane, P. aeruginosa strain B18 could regulate plant hormone production and enhance host-plant resistance to smut pathogen S. scitamineum in a smut-susceptible sugarcane variety to improve growth [25]. Sun proved that the salt-tolerant PCN-producing P. aeruginosa NF011 had the possibility of controlling wheat fungal disease [26].

Previous studies have demonstrated that the main mechanisms of antagonistic antibacterial action include direct secretion of antibacterial substances, competition between nutrition and space, and induction of plant system resistance. This study revealed that strain YY322 produces protease and glucanase, consequently destroying the cell wall of pathogenic fungi, as observed under SEM and TEM, similar to the experimental result of Al-Ghafri [27]. In addition, combined with the antibacterial testing of VOCs, strain YY322 markedly inhibits hyphae development and conidia production, thus effectively controlling growth and reproduction of pathogens. Moreover, WGS analysis showed that strain YY322 contains phzABDEFGIMRS genes, which prove it can produce phenazines with obvious antifungal effects. Liu's study demonstrated that 1-hydroxyphenazine from P. aeruginosa could strongly inhibit the growth of plant pathogenic fungi and bacteria [28]. In addition, strain YY322 could endow host plants with resistance to pathogens, as HCN (hcnABC), surfactin (srfAA), and salicylate (pchA) genes were found in its genome [29,30].

PGP performance evaluation tests found that strain YY322 could fix nitrogen, dissolve phosphorus, and produce siderophore and $\mathrm{NH}_{3}$. The nitrogen on the earth's surface 
mainly exists as $\mathrm{N}_{2}$, but plants cannot directly utilize nitrogen in $\mathrm{N}_{2}$. As a result, nitrogen deficiency is a prevalent problem in farmland soils in China, and it is one of the main factors restricting agricultural production efficiency [31]. The ability to fix nitrogen and produce $\mathrm{NH}_{3}$ of strain YY322 can solve this problem to a certain extent. Similarly, we found its genome contains nitrogen metabolism-related genes, including $g \ln G L$, aatJMPQ, gltBDPST, and nor $B C D E R Q$, proving its nitrogen-fixing ability. Phosphorus is a critical nutrient indispensable for plant life activity, but the effective utilization rate of phosphate fertilizer is low, and its production requires much energy, causing environmental pollution [32]. Phosphorus deficiency in farmland soil is a widespread concern faced by most countries worldwide. Strain YY322 can dissolve insoluble phosphorus in the soil through its own metabolism, converting it into effective phosphorus that plants can absorb and utilize. In our study, strain YY322 genomic sequence analysis also confirmed the existence of $p s t A B C S$, phoABDHRU, and phnCDEFGHIJKLMNP genes, which are responsible for phosphate metabolism. Iron is ubiquitous and abundant in soil, but most iron in soil is insoluble iron oxide, which is challenging to use by plants, so plants frequently suffer from iron deficiency [33]. In view of the result of plate experiments and the discovery of fes, fepA, $m b t H$, cir $A$, fpv $A$, ent $D, a c r A B$, and ser $A B C S$ genes, it is shown that strain YY322 can produce and release siderophores, which chelate ferric ions in soil and form $\mathrm{Fe}^{3+}$-siderophore complexes. They can enter the plant body through a particular plant and microbial cell membrane channel and then be reduced to divalent iron $\left(\mathrm{Fe}^{2+}\right)$, increasing the plant's use of insoluble iron in soil. Concurrently, it also can resist the competition of pathogens for iron and inhibit the reproduction of pathogens [34]. Furthermore, we found the genes (efp, $h f q, \operatorname{mot} A B, f l g B C D E F G H I J K L)$ involved in biofilm formation and the genes (minCDE, lys $C$, $y j b B$ ) involved in colonization in the genome of strain YY322. The formation of biofilm is conducive to the adaptation of microorganisms to poor environments and is closely related to the colonization ability of biocontrol bacteria, which can effectively resist the invasion of pathogens [35].

\section{Materials and Methods}

\subsection{Pathogenic Strains for Antagonistic Test}

Five saffron pathogens (F. oxysporum [36], F. solani [36], P. citreosulfuratum [37], P. citrinum [36], and S. gladioli [38]), isolated and identified from diseased saffron corms by our research team in 2020 , were stored in a refrigerator at $4{ }^{\circ} \mathrm{C}$.

\subsection{Sampling Process and Bacterial Isolation}

In December 2020, rhizosphere soil samples were collected from Chongming district $\left(31.62^{\circ} \mathrm{N}, 121.40^{\circ} \mathrm{E}\right)$, Shanghai, China, for isolating rhizobacterial strains. The corms were uprooted, and the soil adhering to the roots was collected in sterile plastic bags, resembling rhizosphere soil [39]. The soil samples were then cold transferred to the Institute of Chinese Materia Medica at Shanghai University of Traditional Chinese Medicine for immediate processing. The rhizosphere soil was crushed and sieved after being dried in the shade for two weeks. Around $5 \mathrm{~g}$ of rhizosphere soil was mixed with $45 \mathrm{~mL}$ of sterile distilled water in a flask and shaken on a rotary shaker at $30^{\circ} \mathrm{C}$ for $2 \mathrm{~h}$. Following that, $1 \mathrm{~mL}$ of flask suspension was added to a $10 \mathrm{~mL}$ vial and diluted to $10^{-3}, 10^{-4}$, and $10^{-5}$. Approximately $0.2 \mathrm{~mL}$ of each suspension was spread separately on Luria-Bertani (LB) media plates altered with $50 \mu \mathrm{g} / \mathrm{mL}$ cycloheximide to inhibit fungi growth. After that, the plates were placed upside down at $30{ }^{\circ} \mathrm{C}$ for $48 \mathrm{~h}$, and well-isolated single colonies with different morphological characteristics were selected for streaking on fresh LB media plates to obtain the pure culture, which was then stored on LB media slants at $4{ }^{\circ} \mathrm{C}$ in a refrigerator for subsequent experiments.

\subsection{Screening of Antagonistic Bacteria}

The isolated strains were screened in vitro on potato dextrose agar (PDA) medium using the dual-culture method [40]. F. oxysporum, F. solani, and S. gladioli were inoculated 
on PDA medium and activated at $28^{\circ} \mathrm{C}$ for seven days. P. citrinum and P. citreosulfuratum were inoculated on PDA medium through the streaking method of partition and activated at $28{ }^{\circ} \mathrm{C}$ for two days to acquire single colonies. Meanwhile, the antagonistic bacteria obtained from preliminary screening were inoculated on LB medium and cultured at $30{ }^{\circ} \mathrm{C}$ for $24 \mathrm{~h}$. Then, using a puncher, $5 \mathrm{~mm}$ diameter pathogen plugs were obtained and placed in the center of PDA plate, while bacteria were spotted $25 \mathrm{~mm}$ around the plug using sterile toothpicks. PDA plates only with the pathogen plug were employed as controls. All plates were kept at $28{ }^{\circ} \mathrm{C}$ for one to two weeks. Each treatment was replicated three times, and the experiment was repeated twice to determine the best antagonistic bacterium by calculating the inhibition rate. Percentage inhibition was calculated as follows: Inhibition rate $=((\mathrm{control}$ colony diameter - treated colony diameter)/control colony diameter $) \times 100 \%$ [41]

\subsection{Electron Microscopic Analysis}

4.4.1. Observation of the Effect of the Best Antagonistic Bacterium on F. oxysporum and F. solani by SEM

F. oxysporum and F. solani were cultured on PDA medium for ten days according to the above-mentioned method with or without bacterium, after which F. oxysporum and F. solani samples were collected for SEM. The fungal samples were fixed in $2.5 \%(v / v)$ glutaraldehyde for $24 \mathrm{~h}$, rinsed with $0.1 \mathrm{M}$ phosphate buffer ( $\mathrm{pH} 7.2$ ) three times (every time for $15 \mathrm{~min}$ ), fixed in $1 \%(w / v)$ osmic acid for $3 \mathrm{~h}$, rinsed with $0.1 \mathrm{M}$ phosphate buffer ( $\mathrm{pH}$ 7.2) three times (every time for $15 \mathrm{~min}$ ), and dehydrated in an ascending alcohol concentration series (30\%, 50\%, 70\%, 90\%, 100\% three times, for $15 \mathrm{~min}$ each). The samples were dried using a Leica EM CPD300 critical point dryer (Germany) and coated with gold using a Leica EM ACE600 ion sputter coater (Austria). A QUANTA FEG250 scanning electron microscope (Netherlands) was deployed for observing sputter-coated samples.

4.4.2. Observation of the Effect of the Best Antagonistic Bacterium on F. oxysporum and F. solani by TEM

The fungal samples were cut into $1 \mathrm{~mm}^{3}$ pieces by a disposable blade, fixed with $2.5 \%$ $(v / v)$ glutaraldehyde, and stored at $4{ }^{\circ} \mathrm{C}$. Next, they were rinsed with $0.1 \mathrm{M}$ phosphate buffer ( $\mathrm{pH} 7.2$ ) three times (every time for $15 \mathrm{~min}$ ), fixed in $1 \%(w / v)$ osmic acid for $2 \mathrm{~h}$, rinsed with $0.1 \mathrm{M}$ phosphate buffer ( $\mathrm{pH}$ 7.2) three times (every time for $15 \mathrm{~min}$ ), and dehydrated in 30\% ethanol for $15 \mathrm{~min}, 50 \%$ ethanol for $15 \mathrm{~min}, 70 \%$ ethanol-uranyl acetate overnight, $90 \%$ ethanol for $15 \mathrm{~min}, 90 \%$ ethanol:90\% acetone (1:1) for $15 \mathrm{~min}, 90 \%$ acetone for $15 \mathrm{~min}$, and $100 \%$ acetone 3 times (every time for $15 \mathrm{~min}$ ). After that, they were polymerized with acetone:resin (2:1) for $4 \mathrm{~h}$, acetone:resin (1:2) overnight, pure resin twice (every time for $2 \mathrm{~h}$ ), and transferred to the embedding frame for fixation at $37^{\circ} \mathrm{C}$ for $24 \mathrm{~h}$ and $60{ }^{\circ} \mathrm{C}$ for $48 \mathrm{~h}$. Finally, they were sliced into $70 \mathrm{~nm}$ slices using Leica 705902 ultra-thin microtome (Germany), stained with lead citrate for $15 \mathrm{~min}$, rinsed three times with dd $\mathrm{H}_{2} \mathrm{O}$, and dried naturally before being examined using FEI Tecnai G2 Spirit TEM.

\subsection{The Effect of Volatile Organic Compounds (VOCs) of the Best Antagonistic Bacterium on F. oxysporum and F. solani}

In order to assess the production of antifungal VOCs by the bacterium, the double plate assay method [42] was employed, with slight modifications. An appropriate amount of LB medium was poured on the plate's cover and coated with bacterium that was cultivated for $24 \mathrm{~h}$. Concurrently, an appropriate amount of PDA medium was poured on another part of the plate, and a $5 \mathrm{~mm}$ pathogen plug was placed in the center. After that, two parts of the plate were sealed together with parafilm and plastic wrap, and all plates were placed upside down at $28^{\circ} \mathrm{C}$ for seven days. The control treatment was a PDA plate inoculated with only a $5 \mathrm{~mm}$ pathogen plug. Each treatment was replicated three times. The percentage of pathogen growth inhibition caused by VOCs produced by bacterium was determined from the above formula. 


\subsection{Identification of the Best Antagonistic Bacterium}

\subsubsection{Morphological, Physiological, and Biochemical Characterizations}

The morphology of bacterium was observed using SEM with the same method as above. The physiological and biochemical characterizations (gram reaction, growth at $4{ }^{\circ} \mathrm{C}$ and $41{ }^{\circ} \mathrm{C}$, oxidase, catalase, urease, lipase, MR, V-P, gelatin liquefaction, starch hydrolysis, milk coagulation, $\mathrm{H}_{2} \mathrm{~S}$ production, nitrate reduction, and citrate utilization) of bacterium were tested on the basis of "Bergey's Manual of Determinative Bacteriology" [43].

\subsubsection{Molecular Identification}

The DNA of bacterium was extracted using FastPure Bacteria DNA Isolation Mini kit (Vazyme Biotech Co., Ltd., Nanjing, China) according to the manufacturer's instructions. The 16S rRNA gene sequence was amplified using the primers 27F: 5'-AGAGTTTGATCCTGGCTCAG-3' and 1492R: 5'-TACCTTGTTACGACTT-3' [44]. PCR amplifications were conducted in ABI-2720 PCR thermal cycler (Applied Biosystems, CA, USA) as follows: one cycle of $5 \mathrm{~min}$ at $95^{\circ} \mathrm{C}$; followed by 35 cycles of $30 \mathrm{~s}$ at $95^{\circ} \mathrm{C}, 30 \mathrm{~s}$ at $55^{\circ} \mathrm{C}$, and $1 \mathrm{~min}$ at $72{ }^{\circ} \mathrm{C}$; then followed by one cycle of $5 \mathrm{~min}$ at $72{ }^{\circ} \mathrm{C}$. The amplified PCR product was then purified and Sanger sequenced at Personal Biotech Co., Ltd. (Shanghai, China). The obtained $16 \mathrm{~S}$ rDNA sequence of bacterium was examined by the NCBI database using BLAST algorithms at National Center for Biotechnology Information website (https:/ / www.ncbi.nlm.nih.gov/BLAST, accessed on 26 April 2021) [45]. The phylogenetic tree was constructed using the Neighbor-Joining method with MEGA 7.0 software.

\subsection{Detection of Hydrolytic Enzyme Activities}

Since enzymatic cell wall degradation is a potential mechanism for inhibiting fungal growth, the agar diffusion method was used to evaluate whether the bacterium has extracellular hydrolytic enzymes [46]. We utilized chitinase indicator medium (per liter: $\mathrm{MgSO}_{4} \cdot 7 \mathrm{H}_{2} \mathrm{O}, 0.2 \mathrm{~g} ; \mathrm{KCl}, 0.2 \mathrm{~g} ; \mathrm{NH}_{4} \mathrm{H}_{2} \mathrm{PO}_{4}, 1 \mathrm{~g}$; colloidal chitin, $10 \mathrm{~g}$; agar, $18 \mathrm{~g}$ ), protease indicator medium (per liter: skimmed milk, $15 \mathrm{~g}$; agar, $18 \mathrm{~g}$ ), cellulase indicator medium (per liter: Congo red, $0.4 \mathrm{~g} ; \mathrm{MgSO}_{4} \cdot 7 \mathrm{H}_{2} \mathrm{O}, 0.5 \mathrm{~g} ; \mathrm{NaCl}, 0.5 \mathrm{~g} ; \mathrm{KH}_{2} \mathrm{PO}_{4}, 1 \mathrm{~g} ;\left(\mathrm{NH}_{4}\right)_{2} \mathrm{SO}_{4}, 2 \mathrm{~g}$; CMC-Na, 2 g; agar, $18 \mathrm{~g}$ ) and glucanase indicator medium (per liter: $\mathrm{FeSO}_{4}, 0.01 \mathrm{~g}$; Congo red, $0.05 \mathrm{~g} ; \mathrm{KCl}, 0.5 \mathrm{~g} ; \mathrm{MgSO}_{4}, 0.5 \mathrm{~g} ; \mathrm{K}_{2} \mathrm{HPO}_{4}, 1 \mathrm{~g}$; $\mathrm{NaNO}_{3}, 2 \mathrm{~g}$; $\beta$-glucan, $2 \mathrm{~g}$; agar, $18 \mathrm{~g}$ ). The bacterium was spotted on the above-mentioned medium with a sterile toothpick and incubated at $30^{\circ} \mathrm{C}$ for $48 \mathrm{~h}$. A distinct halo was observed surrounding colonies grown on specific agar media, testifying to the existence of extracellular hydrolytic enzymes. Each experiment was replicated three times.

\subsection{Assessment of PGP Potential}

Phosphate solubilization was qualitatively determined using Esmaeel's methodology [47]. Potassium dissolution was qualitatively determined using Wang's methodology [48]. Atmospheric nitrogen fixation was qualitatively determined using Estrada-De Los Santos's methodology [49]. ACC deaminase enzyme production was qualitatively determined using Penrose and Glick's methodology [50]. IAA production was qualitatively determined using Dowarah's methodology [51]. $\mathrm{NH}_{3}$ production was qualitatively determined using Dutta and Thakur's methodology [52]. Siderophore production was qualitatively determined using Dukare's methodology [53]. Each experiment was replicated three times.

\subsection{Whole Genome Sequencing (WGS) of the Best Antagonistic Bacterium}

The bacterium was inoculated into a clear and transparent LB liquid medium and cultured in a constant temperature shaker at $200 \mathrm{rpm}$ at $30{ }^{\circ} \mathrm{C}$. When the OD600 was about 0.6 , the bacterial solution was centrifuged at $8000 \mathrm{rpm}$ for $5 \mathrm{~min}$ at $4{ }^{\circ} \mathrm{C}$ to collect the bacterial cells. Then the cells were gently washed with an appropriate amount of PBS buffer, and the supernatant was removed completely. The cells were quick-frozen 
with liquid nitrogen for $15 \mathrm{~min}$ and then cold-transported to Personal Biotech Co., Ltd. (Shanghai, China) for whole-genome sequencing analysis.

The genomic DNA was extracted using the Cetyltrimethyl Ammonium Bromide (CTAB) method with minor modifications, after which the DNA concentration, quality, and integrity were determined by a Qubit Flurometer (Invitrogen, Carlsbad, CA, USA) and a NanoDrop Spectrophotometer (Thermo Fisher Scientific, Waltham, MA, USA). Sequencing libraries were generated by the TruSeq DNA Sample Preparation Kit (Illumina, Ipswich, CA, USA) and the Template Prep Kit (Pacific Biosciences, Menlo Park, CA, USA). The genome sequencing was then performed by the Pacific Biosciences platform and the Illumina Miseq platform. Data assembly proceeded after adapter contamination removal and data filtering using AdapterRemoval [54] and SOAPec [55]. The filtered reads were assembled by SPAdes [56] and A5-miseq [57] to construct scaffolds and contigs. Canu [58] software was applied to assemble the data acquired by Pacbio platform sequencing. Afterwards, whole assembled results were integrated to generate a complete sequence, and the genome sequence was obtained after correction using pilon software [59].

Genome function element prediction contained the forecast of coding-gene, non-coding RNA, and clustered regularly interspaced short palindromic repeats (CRISPRs). Gene prediction was performed by Glimmer 3.02 [60]. tRNAscan-SE [61], RNAmmer [62], and Rfam [63] were used to discover tRNA, rRNA, and other ncRNA, respectively. CRISPRs were identified by the CRISPR recognition tool [64]. Function annotation was completed by blast search against GO (Gene Ontology) [65], COG (Cluster of Orthologous Groups of proteins) [66], and KEGG (Kyoto Encyclopedia of Gene and Genomes) [67]. Subsequently, Carbohydrate-Active enzymes and Bioactive secondary metabolites were predicted with CAZymes (Carbohydrate-Active enzymes) database [68] and antiSMASH 6.0.1 (https: / / antismash.secondarymetabolites.org/ \#!/start, accessed on 10 October 2021), respectively. Finally, CGview [69] was used to give an overview of the genome information.

\section{Conclusions}

In summary, in the light of this study, we consider that P. aeuroginosa could be employed as a biocontrol agent against pathogenic fungi of saffron, and preliminary tests indicate that it possesses PGPR traits, consistent with Islam's conclusion [70]. It is worth mentioning that this is the first report that $P$. aeruginosa has an antagonistic effect on P. citreosulfuratum, P. citrinum, and S. gladioli. In consideration of the above results, we are convinced that strain YY322 can be developed into a saffron microbial fertilizer. We plan to further verify the antagonistic and PGP effects of strain YY322 in indoor and field trials. Meanwhile, more extensive and in-depth research is required to overcome future problems and challenges with regard to saffron production.

Supplementary Materials: The following are available online at https: / www.mdpi.com/article/ 10.3390/pathogens10111423/s1, Figure S1: hydrolytic enzymes activities, Figure S2: plant growth promoting attributes; Table S1: Statistics of open reading frame (OFR) predictions, Table S2: Statistics of non-coding RNA predictions, Table S3: CRISPRs prediction results.

Author Contributions: S.H.: Validation, Data curation, writing-original draft; X.W.: Investigation, Sample collection; W.S.: Investigation, Data analysis; L.W.: Supervision, Project administration; W.L.: Conceptualization, writing-review and editing, Funding acquisition. All authors have read and agreed to the published version of the manuscript.

Funding: This research was funded by the National Natural Science Foundation of China (81673541).

Institutional Review Board Statement: Not applicable.

Informed Consent Statement: Not applicable.

Data Availability Statement: Not applicable. 
Acknowledgments: We sincerely thank Min Lu and Yi Jiang from the Experiment Center for Science and Technology of Shanghai University of Traditional Chinese Medicine for their help in microscopic observation. We also thank Xinmin Zhao of Shanghai Fanjing Biotechnology Co., Ltd. for his help in sample collection.

Conflicts of Interest: The authors declare that they have no known competing financial interests or personal relationships that could have appeared to influence the work reported in this paper.

\section{References}

1. Patel, S.; Sarwat, M.; Khan, T.H. Mechanism behind the anti-tumour potential of saffron (Crocus sativus L.): The molecular perspective. Crit. Rev. Oncol. Hematol. 2017, 115, 27-35. [CrossRef] [PubMed]

2. Kong, W.; An, H.; Zhang, J.; Sun, L.; Nan, Y.; Song, A.; Zhou, L. Development of a high-performance liquid chromatography with tandem mass spectrometry method for identifying common adulterant content in saffron (Crocus sativus L.). J. Pharm. Pharmacol. 2019, 71, 1864-1870. [CrossRef]

3. Leone, S.; Recinella, L.; Chiavaroli, A.; Orlando, G.; Ferrante, C.; Leporini, L.; Brunetti, L.; Menghini, L. Phytotherapic use of the Crocus sativus L. (Saffron) and its potential applications: A brief overview. Phytother. Res. 2018, 32, $2364-2375$. [CrossRef] [PubMed]

4. Zhang, R.; Vivanco, J.M.; Shen, Q. The unseen rhizosphere root-soil-microbe interactions for crop production. Curr. Opin. Microbiol. 2017, 37, 8-14. [CrossRef]

5. Hartmann, A.; Rothballer, M.; Schmid, M. Lorenz Hiltner, a pioneer in rhizosphere microbial ecology and soil bacteriology research. Plant Soil 2007, 312, 7-14. [CrossRef]

6. Berendsen, R.L.; Pieterse, C.M.; Bakker, P.A. The rhizosphere microbiome and plant health. Trends Plant Sci. 2012, 17, 478-486. [CrossRef]

7. Wang, X.; Wang, M.; Xie, X.; Guo, S.; Zhou, Y.; Zhang, X.; Yu, N.; Wang, E. An amplification-selection model for quantified rhizosphere microbiota assembly. Sci. Bull. 2020, 65, 983-986. [CrossRef]

8. Philippot, L.; Raaijmakers, J.M.; Lemanceau, P.; van der Putten, W.H. Going back to the roots: The microbial ecology of the rhizosphere. Nat. Rev. Microbiol. 2013, 11, 789-799. [CrossRef]

9. Asghari, B.; Khademian, R.; Sedaghati, B. Plant growth promoting rhizobacteria (PGPR) confer drought resistance and stimulate biosynthesis of secondary metabolites in pennyroyal (Mentha pulegium L.) under water shortage condition. Sci. Hortic. 2020, 263, 109132. [CrossRef]

10. Hammami, I.; Hsouna, A.B.; Hamdi, N.; Gdoura, R.; Triki, M.A. Isolation and characterization of rhizosphere bacteria for the biocontrol of the damping-off disease of tomatoes in Tunisia. Comptes Rendus Biol. 2013, 336, 557-564. [CrossRef] [PubMed]

11. Yang, W. Components of rhizospheric bacterial communities of barley and their potential for plant growth promotion and biocontrol of Fusarium wilt of watermelon. Braz. J. Microbiol. 2019, 50, 749-757. [CrossRef]

12. Li, J.; Hu, M.; Xue, Y.; Chen, X.; Lu, G.; Zhang, L.; Zhou, J. Screening, Identification and Efficacy Evaluation of Antagonistic Bacteria for Biocontrol of Soft Rot Disease Caused by Dickeya zeae. Microorganisms 2020, 8, 697. [CrossRef] [PubMed]

13. Haas, D.; Defago, G. Biological control of soil-borne pathogens by fluorescent pseudomonads. Nat. Rev. Microbiol. 2005, 3, 307-319. [CrossRef] [PubMed]

14. He, Y.; Pantigoso, H.A.; Wu, Z.; Vivanco, J.M. Co-inoculation of Bacillus sp. and Pseudomonas putida at different development stages acts as a biostimulant to promote growth, yield and nutrient uptake of tomato. J. Appl. Microbiol. 2019, 127, 196-207. [CrossRef]

15. Chandra, H.; Kumari, P.; Bisht, R.; Prasad, R.; Yadav, S. Plant growth promoting Pseudomonas aeruginosa from Valeriana wallichii displays antagonistic potential against three phytopathogenic fungi. Mol. Biol. Rep. 2020, 47, 6015-6026. [CrossRef]

16. Jimenez, J.A.; Novinscak, A.; Filion, M. Pseudomonas fluorescens LBUM677 differentially increases plant biomass, total oil content and lipid composition in three oilseed crops. J. Appl. Microbiol. 2020, 128, 1119-1127. [CrossRef]

17. Hua, G.K.H.; Wang, L.; Chen, J.; Ji, P. Biological control of Fusarium wilt on watermelon by fluorescent pseudomonads. Biocontrol Sci. Technol. 2019, 30, 212-227. [CrossRef]

18. Tagele, S.B.; Lee, H.G.; Kim, S.W.; Lee, Y.S. Phenazine and 1-Undecene Producing Pseudomonas chlororaphis subsp. aurantiaca Strain KNU17Pc1 for Growth Promotion and Disease Suppression in Korean Maize Cultivars. J. Microbiol. Biotechnol. 2019, 29, 66-78. [CrossRef]

19. Zhang, Y.; Chen, P.; Ye, G.; Lin, H.; Ren, D.; Guo, L.; Zhu, B.; Wang, Z. Complete Genome Sequence of Pseudomonas Parafulva PRS0911288, a Biocontrol Strain Produces the Antibiotic Phenazine-1-carboxylic Acid. Curr. Microbiol. 2019, 76, 1087-1091. [CrossRef]

20. Khorasanchi, Z.; Shafiee, M.; Kermanshahi, F.; Khazaei, M.; Ryzhikov, M.; Parizadeh, M.R.; Kermanshahi, B.; Ferns, G.A.; Avan, A.; Hassanian, S.M. Crocus sativus a natural food coloring and flavoring has potent anti-tumor properties. Phytomedicine 2018, 43 , 21-27. [CrossRef] [PubMed]

21. Abu-Izneid, T.; Rauf, A.; Khalil, A.A.; Olatunde, A.; Khalid, A.; Alhumaydhi, F.A.; Aljohani, A.S.M.; Sahab Uddin, M.; Heydari, M.; Khayrullin, M.; et al. Nutritional and health beneficial properties of saffron (Crocus sativus L): A comprehensive review. Crit. Rev. Food Sci. Nutr. 2020, 10, 1-24. [CrossRef] [PubMed]

22. Cardone, L.; Castronuovo, D.; Perniola, M.; Cicco, N.; Candido, V. Evaluation of corm origin and climatic conditions on saffron (Crocus sativus L.) yield and quality. J. Sci. Food Agric. 2019, 99, 5858-5869. [CrossRef] [PubMed] 
23. Dean, R.; Van Kan, J.A.; Pretorius, Z.A.; Hammond-Kosack, K.E.; Di Pietro, A.; Spanu, P.D.; Rudd, J.J.; Dickman, M.; Kahmann, R.; Ellis, J.; et al. The Top 10 fungal pathogens in molecular plant pathology. Mol. Plant Pathol. 2012, 13, 414-430. [CrossRef]

24. Yuan, J.; Zhao, J.; Wen, T.; Zhao, M.; Li, R.; Goossens, P.; Huang, Q.; Bai, Y.; Vivanco, J.M.; Kowalchuk, G.A.; et al. Root exudates drive the soil-borne legacy of aboveground pathogen infection. Microbiome 2018, 6, 156. [CrossRef] [PubMed]

25. Singh, P.; Singh, R.K.; Guo, D.J.; Sharma, A.; Singh, R.N.; Li, D.P.; Malviya, M.K.; Song, X.P.; Lakshmanan, P.; Yang, L.T.; et al. Whole Genome Analysis of Sugarcane Root-Associated Endophyte Pseudomonas aeruginosa B18-A Plant Growth-Promoting Bacterium With Antagonistic Potential Against Sporisorium scitamineum. Front. Microbiol. 2021, 12, 628376. [CrossRef] [PubMed]

26. Sun, X.; Xu, Y.; Chen, L.; Jin, X.; Ni, H. The salt-tolerant phenazine-1-carboxamide-producing bacterium Pseudomonas aeruginosa NF011 isolated from wheat rhizosphere soil in dry farmland with antagonism against Fusarium graminearum. Microbiol. Res. 2021, 245, 126673. [CrossRef]

27. Al-Ghafri, H.M.; Velazhahan, R.; Shahid, M.S.; Al-Sadi, A.M. Antagonistic activity of Pseudomonas aeruginosa from compost against Pythium aphanidermatum and Fusarium solani. Biocontrol Sci. Technol. 2020, 30, 642-658. [CrossRef]

28. Liu, T.T.; Ye, F.C.; Pang, C.P.; Yong, T.Q.; Tang, W.D.; Xiao, J.; Shang, C.H.; Lu, Z.J. Isolation and identification of bioactive substance 1-hydroxyphenazine from Pseudomonas aeruginosa and its antimicrobial activity. Lett. Appl. Microbiol. 2020, 71, 303-310. [CrossRef] [PubMed]

29. Xu, W.F.; Ren, H.S.; Ou, T.; Lei, T.; Wei, J.H.; Huang, C.S.; Li, T.; Strobel, G.; Zhou, Z.Y.; Xie, J. Genomic and Functional Characterization of the Endophytic Bacillus subtilis 7PJ-16 Strain, a Potential Biocontrol Agent of Mulberry Fruit Sclerotiniose. Microb. Ecol. 2019, 77, 651-663. [CrossRef]

30. Chenniappan, C.; Narayanasamy, M.; Daniel, G.M.; Ramaraj, G.B.; Ponnusamy, P.; Sekar, J.; Vaiyapuri Ramalingam, P. Biocontrol efficiency of native plant growth promoting rhizobacteria against rhizome rot disease of turmeric. Biol. Control. 2019, 129, 55-64. [CrossRef]

31. Tao, K.; Kelly, S.; Radutoiu, S. Microbial associations enabling nitrogen acquisition in plants. Curr. Opin. Microbiol. 2019, 49, 83-89. [CrossRef] [PubMed]

32. Adnan, M.; Shah, Z.; Fahad, S.; Arif, M.; Alam, M.; Khan, I.A.; Mian, I.A.; Basir, A.; Ullah, H.; Arshad, M.; et al. PhosphateSolubilizing Bacteria Nullify the Antagonistic Effect of Soil Calcification on Bioavailability of Phosphorus in Alkaline Soils. Sci. Rep. 2017, 7, 16131. [CrossRef]

33. Aeron, A.; Khare, E.; Jha, C.K.; Meena, V.S.; Aziz, S.M.A.; Islam, M.T.; Kim, K.; Meena, S.K.; Pattanayak, A.; Rajashekara, H.; et al. Revisiting the plant growth-promoting rhizobacteria: Lessons from the past and objectives for the future. Arch. Microbiol. 2020, 202, 665-676. [CrossRef]

34. Gu, S.; Wei, Z.; Shao, Z.; Friman, V.P.; Cao, K.; Yang, T.; Kramer, J.; Wang, X.; Li, M.; Mei, X.; et al. Competition for iron drives phytopathogen control by natural rhizosphere microbiomes. Nat. Microbiol. 2020, 5, 1002-1010. [CrossRef] [PubMed]

35. Ongena, M.; Jacques, P. Bacillus lipopeptides: Versatile weapons for plant disease biocontrol. Trends Microbiol. 2008, 16, 115-125. [CrossRef]

36. Gupta, V.; Sharma, A.; Rai, P.K.; Gupta, S.K.; Singh, B.; Sharma, S.K.; Singh, S.K.; Hussain, R.; Razdan, V.K.; Kumar, D.; et al. Corm Rot of Saffron: Epidemiology and Management. Agronomy 2021, 11, 339. [CrossRef]

37. Hu, S.; Sun, W.; Wang, X.; Wang, L.; Li, W. First Report of Black Spot Caused by Penicillium citreosulfuratum on Saffron in Chongming Island, China. Plant Dis. 2021. [CrossRef]

38. Muñoz, R.M.; Lerma, M.L.; Castillo, P.; Armengol, J.; Somoza, E.; Woodhall, J.W. First Report of Stromatinia gladioli Causing Neck and Corm Rot of Crocus sativus in Spain. Plant Dis. 2020, 104, 282. [CrossRef]

39. Rasool, A.; Imran Mir, M.; Zulfajri, M.; Hanafiah, M.M.; Azeem Unnisa, S.; Mahboob, M. Plant growth promoting and antifungal asset of indigenous rhizobacteria secluded from saffron (Crocus sativus L.) rhizosphere. Microb. Pathog. 2021, 150, 104734. [CrossRef] [PubMed]

40. Ren, X.; Zhang, N.; Cao, M.; Wu, K.; Shen, Q.; Huang, Q. Biological control of tobacco black shank and colonization of tobacco roots by a Paenibacillus polymyxa strain C5. Biol. Fertil. Soils 2012, 48, 613-620. [CrossRef]

41. Xie, Z.; Li, M.; Wang, D.; Wang, F.; Shen, H.; Sun, G.; Feng, C.; Wang, X.; Chen, D.; Sun, X. Biocontrol efficacy of Bacillus siamensis LZ88 against brown spot disease of tobacco caused by Alternaria alternata. Biol. Control. 2021, 154, 104508. [CrossRef]

42. Di Francesco, A.; Ugolini, L.; Lazzeri, L.; Mari, M. Production of volatile organic compounds by Aureobasidium pullulans as a potential mechanism of action against postharvest fruit pathogens. Biol. Control. 2015, 81, 8-14. [CrossRef]

43. Guo, D.; Yuan, C.; Luo, Y.; Chen, Y.; Lu, M.; Chen, G.; Ren, G.; Cui, C.; Zhang, J.; An, D. Biocontrol of tobacco black shank disease (Phytophthora nicotianae) by Bacillus velezensis Ba168. Pestic. Biochem. Physiol. 2020, 165, 104523. [CrossRef] [PubMed]

44. Frank, J.A.; Reich, C.I.; Sharma, S.; Weisbaum, J.S.; Wilson, B.A.; Olsen, G.J. Critical evaluation of two primers commonly used for amplification of bacterial 16S rRNA genes. Appl. Environ. Microbiol. 2008, 74, 2461-2470. [CrossRef]

45. Yang, Y.; Zhang, S.W.; Li, K.T. Antagonistic activity and mechanism of an isolated Streptomyces corchorusii stain AUH-1 against phytopathogenic fungi. World J. Microbiol. Biotechnol. 2019, 35, 145. [CrossRef] [PubMed]

46. Wang, X.; Xiao, C.; Ji, C.; Liu, Z.; Song, X.; Liu, Y.; Li, C.; Yan, D.; Li, H.; Qin, Y.; et al. Isolation and characterization of endophytic bacteria for controlling root rot disease of Chinese jujube. J. Appl. Microbiol. 2021, 130, 926-936. [CrossRef]

47. Esmaeel, Q.; Jacquard, C.; Clement, C.; Sanchez, L.; Ait Barka, E. Genome sequencing and traits analysis of Burkholderia strains reveal a promising biocontrol effect against grey mould disease in grapevine (Vitis vinifera L.). World J. Microbiol. Biotechnol. 2019, 35, 40. [CrossRef] [PubMed] 
48. Wang, X.; Wang, C.; Li, Q.; Zhang, J.; Ji, C.; Sui, J.; Liu, Z.; Song, X.; Liu, X. Isolation and characterization of antagonistic bacteria with the potential for biocontrol of soil-borne wheat diseases. J. Appl. Microbiol. 2018, 125, 1868-1880. [CrossRef] [PubMed]

49. Estrada-De Los Santos, P.; Bustillos-Cristales, R.; Caballero-Mellado, J. Burkholderia, a genus rich in plant-associated nitrogen fixers with wide environmental and geographic distribution. Appl. Environ. Microbiol. 2001, 67, 2790-2798. [CrossRef]

50. Husen, E.; Wahyudi, A.T.; Suwanto, A.; Saraswati, R. Soybean Seedling Root Growth Promotion by 1-Aminocyclopropane-1Carboxylate Deaminase-Producing Pseudomonads. Indones. J. Agric. Sci. 2016, 10, 19-25. [CrossRef]

51. Dowarah, B.; Agarwal, H.; Krishnatreya, D.B.; Sharma, P.L.; Kalita, N.; Agarwala, N. Evaluation of seed associated endophytic bacteria from tolerant chilli cv. Firingi Jolokia for their biocontrol potential against bacterial wilt disease. Microbiol. Res. 2021, 248, 126751. [CrossRef] [PubMed]

52. Dutta, J.; Thakur, D. Evaluation of Antagonistic and Plant Growth Promoting Potential of Streptomyces sp. TT3 Isolated from Tea (Camellia sinensis) Rhizosphere Soil. Curr. Microbiol. 2020, 77, 1829-1838. [CrossRef]

53. Dukare, A.; Paul, S. Biological control of Fusarium wilt and growth promotion in pigeon pea (Cajanus cajan) by antagonistic rhizobacteria, displaying multiple modes of pathogen inhibition. Rhizosphere 2021, 17, 100278. [CrossRef]

54. Lindgreen, S. AdapterRemoval: Easy cleaning of next-generation sequencing reads. BMC Res. Notes 2012, 5, 337. [CrossRef]

55. Luo, R.B.; Liu, B.H.; Xie, Y.L.; Li, Z.Y.; Huang, W.H.; Yuan, J.Y.; He, G.Z.; Chen, Y.X.; Pan, Q.; Liu, Y.J.; et al. SOAPdenovo2: An empirically improved memory-efficient short-read de novo assembler. Gigascience 2012, 1, 18. [CrossRef] [PubMed]

56. Bankevich, A.; Nurk, S.; Antipov, D.; Gurevich, A.A.; Dvorkin, M.; Kulikov, A.S.; Lesin, V.M.; Nikolenko, S.I.; Pham, S.; Prjibelski, A.D.; et al. SPAdes: A new genome assembly algorithm and its applications to single-cell sequencing. J. Comput. Biol. 2012, 19, 455-477. [CrossRef] [PubMed]

57. Coil, D.; Jospin, G.; Darling, A.E. A5-miseq: An updated pipeline to assemble microbial genomes from Illumina MiSeq data. Bioinformatics 2015, 31, 587-589. [CrossRef] [PubMed]

58. Koren, S.; Walenz, B.P.; Berlin, K.; Miller, J.R.; Bergman, N.H.; Phillippy, A.M. Canu: Scalable and accurate long-read assembly via adaptive k-mer weighting and repeat separation. Genome Res. 2017, 27, 722-736. [CrossRef]

59. Walker, B.J.; Abeel, T.; Shea, T.; Priest, M.; Abouelliel, A.; Sakthikumar, S.; Cuomo, C.A.; Zeng, Q.; Wortman, J.; Young, S.K.; et al. Pilon: An integrated tool for comprehensive microbial variant detection and genome assembly improvement. PLoS ONE 2014, 9, e112963. [CrossRef] [PubMed]

60. Delcher, A.L.; Harmon, D.; Kasif, S.; White, O.; Salzberg, S.L. Improved microbial gene identification with GLIMMER. Nucleic Acids Res. 1999, 27, 4636-4641. [CrossRef] [PubMed]

61. Lowe, T.M.; Eddy, S. tRNAscan-SE: A program for improved detection of transfer RNA genes in genomic sequence. Nucleic Acids Res. 1997, 25, 955-964. [CrossRef] [PubMed]

62. Lagesen, K.; Hallin, P.; Rodland, E.A.; Staerfeldt, H.H.; Rognes, T.; Ussery, D.W. RNAmmer: Consistent and rapid annotation of ribosomal RNA genes. Nucleic Acids Res. 2007, 35, 3100-3108. [CrossRef]

63. Burge, S.W.; Daub, J.; Eberhardt, R.; Tate, J.; Barquist, L.; Nawrocki, E.P.; Eddy, S.R.; Gardner, P.P.; Bateman, A. Rfam 11.0: 10 years of RNA families. Nucleic Acids Res. 2013, 41, D226-D232. [CrossRef] [PubMed]

64. Bland, C.; Ramsey, T.L.; Sabree, F.; Lowe, M.; Brown, K.; Kyrpides, N.C.; Hugenholtz, P. CRISPR recognition tool (CRT): A tool for automatic detection of clustered regularly interspaced palindromic repeats. BMC Bioinformatics 2007, 8, 209. [CrossRef] [PubMed]

65. Conesa, A.; Gotz, S. Blast2GO: A comprehensive suite for functional analysis in plant genomics. Int. J. Plant Genom. 2008, 2008, 619832. [CrossRef] [PubMed]

66. Powell, S.; Forslund, K.; Szklarczyk, D.; Trachana, K.; Roth, A.; Huerta-Cepas, J.; Gabaldon, T.; Rattei, T.; Creevey, C.; Kuhn, M.; et al. eggNOG v4.0: Nested orthology inference across 3686 organisms. Nucleic Acids Res. 2014, 42, 231-239. [CrossRef]

67. Moriya, Y.; Itoh, M.; Okuda, S.; Yoshizawa, A.C.; Kanehisa, M. KAAS: An automatic genome annotation and pathway reconstruction server. Nucleic Acids Res. 2007, 35, 182-185. [CrossRef]

68. Lombard, V.; Golaconda Ramulu, H.; Drula, E.; Coutinho, P.M.; Henrissat, B. The carbohydrate-active enzymes database (CAZy) in 2013. Nucleic Acids Res. 2014, 42, D490-D495. [CrossRef]

69. Stothard, P.; Wishart, D.S. Circular genome visualization and exploration using CGView. Bioinformatics 2005, 21, 537-539. [CrossRef]

70. Islam, M.A.; Nain, Z.; Alam, M.K.; Banu, N.A.; Islam, M.R. In Vitro study of biocontrol potential of rhizospheric Pseudomonas aeruginosa against Fusarium oxysporum f. sp. cucumerinum. Egypt. J. Biol. Pest Control. 2018, 28, 1. [CrossRef] 